\title{
THE QUALITY OF KINDERGARTEN CARE AS AN IMPORTANT ELEMENT OF THE SUBJECTIVE THEORIES
}

\author{
Jera Gregorc, Jože Štihec*, Mateja Videmšek*, Alenka Cemič, Maja Meško \\ Faculty of Education, University of Ljubljana, Ljubljana, Slovenia \\ * Faculty of Sport, University of Ljubljana, Ljubljana, Slovenia
}

Submitted in March, 2011

BACKGROUND: Pre-school teachers and assistants jointly manage the educational process for pre-school children in kindergartens. The selection of topics and the process orientation depends on their professionalism, which is also reflected in subjective theories influencing also their lifestyle selection.

OBJECTIVE: The authors try to establish the differences in the opinions of the pre-school teachers and assistants on the quality and amount of time which children spend in kindergartens and to establish the differences in their opinions on material conditions for pursuing motor/sports activities. The aim was to establish whether the pre-school teachers apply higher standards for the evaluation of quality of leisure time spent by children and stricter criteria regarding material conditions to pursue motor/sports activities in kindergartens than their assistants.

METHODS: The sample was composed of 810 pre-school teachers and assistants from the whole territory of Slovenia. The sample was not redundant. The data were collected in September 2009, within the scope of a more extensive research project titled "Professional training of education practitioners to implement elements of special pedagogical principles of the Reggio Emilia concept in the field of pre-school education from the year 2008 to 2013" and were analyzed with basic statistical parameters. The data were processed by applying the SPSS statistical programme for Windows. Every statistically significant conclusion was accepted at the risk level of 5\%.

RESULTS: The analysis of the results showed that the opinions of the pre-school teachers and assistants on the manner of children spending their leisure time were not statistically different. However, there were differences regarding their evaluation of the amount and quality of sports equipment and in their attitudes to motor/sports activities, in favour of pre-school teachers, who also take up motor/sports activities more often than the assistants do. We also established that more motor/sports active the pre-school teachers are during the week, the more often they participate in motor/sports activities in kindergartens, as well.

CONCLUSIONS: The results of our research direct us towards providing a wider range of seminars within inservice teacher training also for the assistants and to contemplate offering recreational activities for the kindergarten staff, which shall contribute to a comprehensive bio-psycho-social status of an individual and to reshaping his lifestyle from the sedentary to the active one.

Keywords: Assistants, pre-school teachers, lifestyle, curriculum.

\section{INTRODUCTION}

The organization and detailed content of life and work are set out by the kindergarten in the annual work plan, adopted by the council of the kindergarten (Article 21 of pre-school institutions act, 1996), in which among others also the facilities needed in the kindergarten to participate in physical activities are identified. The annual plan for an individual teaching group is then devised on the basis of the Pre-school curriculum (1999) approved by professional Council of the Republic of Slovenia for General Education; whereby also special features of the kindergarten (material, geographical, weather conditions, personnel and interests of children) and children should be taken into account. In the areas where there is snow in winter, kindergarten authorities shall provide more activities on snow and ice in comparison with those which lack these natural features; the same fact applies to the kindergartens which have the opportunity to arrange water games and swimming in their vicinity (Videmšek \& Pišot, 2007). Temple and O'Commor (2011) point out that environments provide opportunities and the structure to engage children in meaningful motor/sports experiences.

In compliance with the instructions of the valid Curriculum for kindergartens pre-school teachers decide on the amount of time to be dedicated to individual proposed content. The process and development oriented curriculum gives the pre-school teachers much freedom regarding the selection of various content in order to reach the same goals. The autonomous selection applies to every basic area of the curriculum, thus also to 
movement (Zajec, 2010). Previous research in the field of movement demonstrated that material conditions, personnel and organizational factors have impact on the frequency of integrating organized motor/sports activities in the kindergarten (Zajec, Videmšek, Štihec, \& Simunič, 2010). The same researchers established that of the above mentioned factors personnel is the key factor contributing to the formation of the regression equation for identifying the relationship between organized motor/ sports activities in the kindergarten and other variables, such as material conditions, content and personnel.

The term hidden curriculum refers to all the acts, which are not explicitly written down in the valid curriculum, and which are reflected in subjective, personal, implicit theories and preschool teacher's attitude to the education. Taking into consideration the fact that the hidden curriculum (Špoljar, 1993) substantially defines the educational process and has impact on the interaction between the pre-school teacher and the child and is reflected in subjective theories, the lifestyle of pre-school teachers is of prime importance (Zajec \& Cemič, 2010). The hidden curriculum does not apply only to ideologically charged contents (Bahovec \& Kodelja, 1996), but substantially interferes with the organization and activities of the kindergarten as a whole. The lifestyle of a preschool teacher influences subjective theories, which in turn have a powerful impact on the teaching orientation and are also reflected in the directions and manner of activities an individual pre-school teacher is to pursue (Zajec \& Cemič, 2010). Apart from the already mentioned facts one cannot neglect the fact that the performance in the pre-school teaching profession depends also on physical fitness of pre-school teachers, because they face numerous physical challenges on a daily basis.

The awareness that motor/sports activities, especially when performed outdoors, are crucial for harmonious physical development of each child, obliges parents, preschool teachers, pedagogues, and sports professionals to ensure a suitable amount and quality of motor/sports activity performance. Early childhood development is very dynamic and comprehensive, thus motor/sports activities are of outstanding importance. Apart from the fact that movement is an important means of acquiring various information and gathering new experience a child develops movement and functional capabilities when practising it. It is also agreed that during the preschool years, children should be encouraged to practice movement skills and engage in appropriate physical activity for health, social, and psychological reasons (Shilton \& Naughton, 2001). Early childhood forms a unique period where children undergo significant social, intellectual, emotional, and physical development (Weiss, 2000). It is agreed that enhancement of movement skills play an important role in the development of children within the physical domain, with potential carry-over into the social and cognitive domains (Gab- bard, 1988). Motor/sports activities, such as manipulation opportunities with a variety of equipment, and both locomotive and non-locomotive activities, should form the basis of a young child's pre-school movement experience (Gallahue \& Ozmun, 2006; Sanders, 1992).

The role of the immediate environment, pre-school teachers, their assistants and parents is thus crucial for the development of a behavioural style of each child, and consequently, of life quality of each individual (Plomin, Chipuer, \& Neiderhiser, 1994).

It has been proven that prior to its birth a child already perceives stimuli from the environment that can influence its later development. Following the birth it is the very environment into which a child is born, which is of prime importance for his cognitive, physical, movement, emotional and social development; consequently, the factors influencing the child's development can be divided into three groups, i.e. hereditary, environmental factors and the child's own activity (self-activity) (Musek \& Pečjak, 1997; Videmšek, Štihec, \& Karpljuk, 2008). Simultaneous emergence of all three factors account for capabilities, characteristic features and properties of each individual. The child's development should be planned in an overall manner, whereby all the factors influencing the creation of a healthy lifestyle should be taken into account (Zajec, 2009).

From the topic of the present research the importance of motor/sports activities during childhood for one's health, as well as for the development of every movement and functional activities is to be inferred. Appropriate movement activities and spending leisure time outdoors, as well as the quality of the environment have a powerful influence on the later choice of a healthy lifestyle of each individual; also the role model of a pre-school teacher and her assistant, as well as material conditions for work in pre-school institutions are also among the decisive factors.

The rationale of this study is the fact that with knowing the differences in opinions of pre-school teachers and assistants on the importance of children spending quality leisure time and with the theory that the subjective theories significantly influence the teaching orientation this study pointed out the importance of educational process not only for pre-school teachers but also for their assistants. With finding out whether the criteria to assess the quality of material conditions for initiating motor/sports activities of pre-school teachers, who influence the educational process in a more powerful manner than the assistants, we also see the importance of the study in rationale of lifelong learning for pre-school teachers and their assistants.

The aim of this research is to establish the differences of opinions between pre-school teachers and their assistants on the quality and amount of time spent by children in pre-school institutions and to establish the differences of opinions on material conditions provided. 


\section{METHODS}

\section{Sample of respondents}

The sample of respondents was composed of 810 male and female pre-school teachers who participated in the first part of "Professional training of educational staff to implement elements of special pedagogical principles of the Reggio Emilia concept in the area of pre-school education". The data was gathered in September 2009. The sample of respondents was not redundant. All respondents participated voluntarily and had the freedom to choose not to participate.

$98.4 \%$ of the respondents were female pre-school teachers and $1.6 \%$ male teachers of the rural $(26.9 \%)$, suburban $(22.9 \%)$ and urban environment (50.2\%). As regards the work place $66.8 \%$ of pre-school teachers and $33.2 \%$ of their assistants participated in the research. The average age of the respondents was 39.6 years.

The whole process of data collection was implemented in compliance with the requirements of Personal Data Protection Act (Official gazette of the Republic of Slovenia, No. 59/1999).

\section{Sample of variables}

The sample of variables of the whole research comprised all the fields that are covered by the curriculum for pre-school institutions and was designed by the coordinators of individual areas within the project titled "Professional training of pedagogical staff to implement elements of special pedagogical principles of the Reggio Emilia concept in the field of pre-school education".

Uniform questionnaires were compiled for pre-school teachers and their assistants. The measuring characteristic of the questionnaire had been validated. In the present research only the variables related to the area of movement are shown.

Questions were related to:

- the view of the quality and quantity of time spent by children in pre-school institutions,

- the opinions on material conditions provided,
- the frequency of motor/sports activities of children and

- the frequency of motor/sports activities of pre-school teachers and assistants.

A questionnaire contained 20 questions, closed and semi-open type. The views of respondents were measured with five-point Likert's scale (ranging from 1 to 5 , in which 5 stands for very much and 1 for very little).

\section{Data processing methods}

The data were processed by the SPSS - 16.0 for Windows (Statistical package for social sciences Inc., Chicago IL). In order to calculate the frequencies of individual responses in the questionnaires frequencies was used. On numerical variables and also on other suitably transformed variables mean, standard deviation, variance analysis and correlation (analysis of the connection among the variables) were used. Statistic significance was checked at the risk level of $5 \%(p=0.05)$. Data were arranged in tables and figures.

\section{RESULTS}

Pre-school teachers and their assistants were asked about children's leisure time in their teaching groups in individual places. We inferred that children of our research sample spend $10.1 \%$ of their leisure sitting outdoors, whereas $28 \%$ of their leisure is spent sitting in the play rooms on average, and $16.8 \%$ of their leisure is spent sitting in the joint premises.

TABLE 1 shows the frequency of grades of the preschool teachers and their assistants as regards the movement activities of the children on a scale ranging from 1 to 5 . It is evident that $60.3 \%$ of both responding groups believe that children of their respective pre-school institutions are movement active to a great extent. However, this assessment was provided by almost $10 \%$ more preschool teachers than their assistants. The differences between both groups were checked by chi-square test, which showed no statistically significant differences.

\section{TABLE 1}

Different ways in which children spend their leisure in pre-school instituitons per day outdoors, in the play room and in the joint premises in the seated pose

\begin{tabular}{|c|c|c|c|c|c|}
\hline Children spend their leisure in different ways. & $\mathbf{N}$ & Min. & Max. & Mean value & $\begin{array}{l}\text { Standard } \\
\text { deviation }\end{array}$ \\
\hline $\begin{array}{l}\text { What percentage of time, that a child spends outdoors per day, is } \\
\text { he/she in the seated pose? }\end{array}$ & 705 & 0 & 90 & 10.1 & 9.31 \\
\hline $\begin{array}{l}\text { What percentage of time, that a child spends per day in the play } \\
\text { room, is he/she in the seated pose? }\end{array}$ & 741 & 1 & 90 & 28.0 & 17.28 \\
\hline $\begin{array}{l}\text { What percentage of time, that a child spends per day in the joint } \\
\text { premises, is he/she in the seated pose? }\end{array}$ & 628 & 0 & 90 & 16.8 & 19.46 \\
\hline
\end{tabular}

Legend: $\mathrm{N}$ - the number of responses, min. - minimum value, max. - maximum value, mean value - the percentage of time, that a child spends per day in a certain place in a certain position 
Fig. 1 shows the differences between the pre-school teachers and assistants in average value regarding the frequency of motor/sports activities of the children in their pre-school institutions. The average value of all the grades amounts to 4.54 with a standard deviation of 0.61. A more detailed analysis showed differences between the pre-school teachers and assistants, in favour of the pre-school teachers believing that children are provided with more motor/sports activities than it is perceived by the assistants. Despite the existing differences they are not statistically significant, as the ANOVA $(\mathrm{F}$ value $=3.352, \mathrm{p}=0.068)$ that for independent samples did not show statistically significant differences between both groups.

Furthermore, we analysed the opinions of pre-school teachers on motor/sports activities of children in their respective pre-school institutions were established by posing the question "How well do you think children in your kindergartens are physically fit? Mark the appropriate grade taking into consideration your group average." The opinions of the pre-school teachers and their assistants are presented in TABLE 3 taking into account a scale ranging from 1 to 5 , whereby 1 stands for very bad physical fitness of a child and 5 for very good physical fitness. The results show that the mean value of all the grades is 3.98 with a standard deviation 0.68 . The opinions of the pre-school teachers and the assistants are not mutually statistically different.

TABLE 2 shows the assessment of the responding pre-school teachers and assistants of the amount and quality of sports equipment at disposal in their respective kindergartens. The average grade of the amount of various sports equipment is 3.22 with a standard deviation of 1.05 (on a scale ranging from 1 to 5, whereby 5 stands for very good and 1 for very bad). The preschool teachers assessed also the quality of sports equipment using the same scale. TABLE 2 shows that the
Fig. 1

The average value and standard deviation of the assessment of the frequency of motor/sport activities of children in the kindergarden per week between the assistants and the pre-school teachers

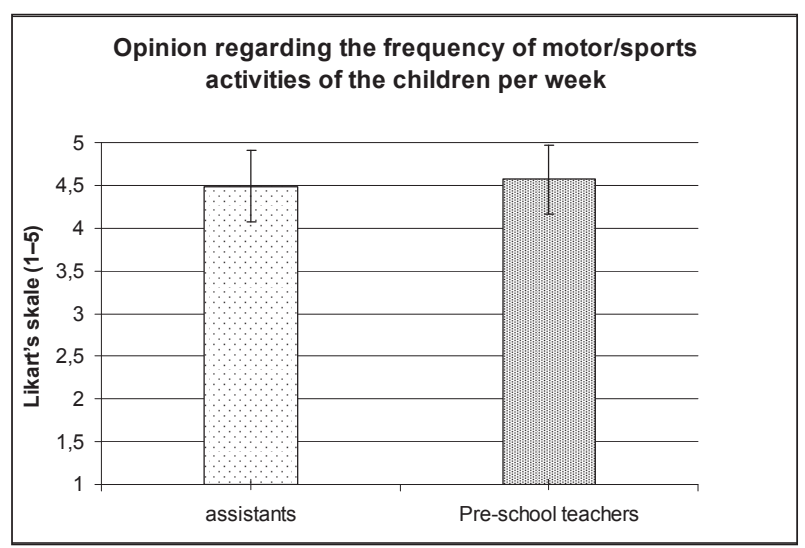

Fig. 2

Analysis of the motor/sports activities of the pre-school teachers and assistants

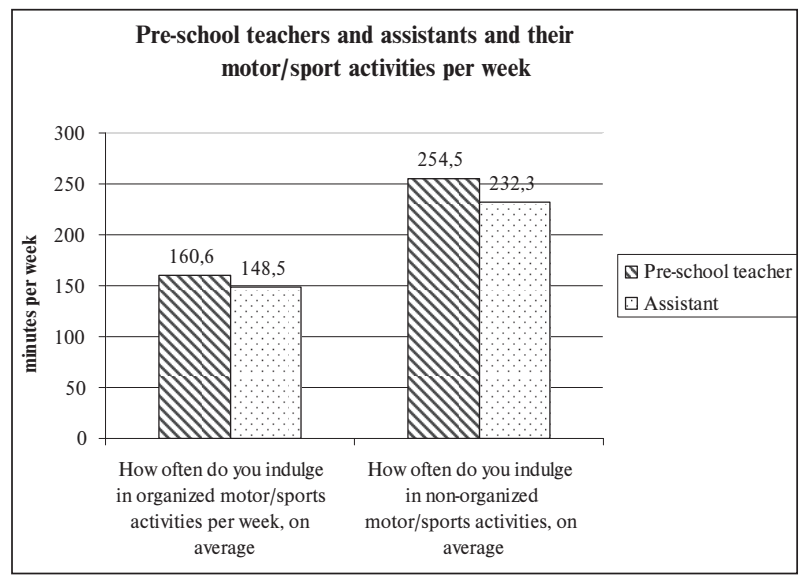

TABLE 2

The quantity and the quality of the sports equipment

\begin{tabular}{|c|c|c|c|c|c|c|}
\hline \multirow[b]{2}{*}{ Sports equipment } & & \multirow[b]{2}{*}{$\mathbf{N}$} & \multirow[b]{2}{*}{ Mean value } & \multirow[b]{2}{*}{$\begin{array}{l}\text { Standard } \\
\text { deviation }\end{array}$} & \multicolumn{2}{|c|}{ ANOVA } \\
\hline & & & & & $\mathbf{F}$ & $\begin{array}{c}\text { Statistical } \\
\text { significance }\end{array}$ \\
\hline \multirow{3}{*}{$\begin{array}{l}\text { Could you, please, assess the quantity of the sports } \\
\text { equipment that is at disposal in your kindergarden? }\end{array}$} & $\begin{array}{l}\text { Pre-school } \\
\text { teacher }\end{array}$ & 529 & 3.18 & 1.06 & 4.014 & $.045^{*}$ \\
\hline & Assistant & 262 & 3.34 & 1.01 & & \\
\hline & Together & 791 & 3.23 & 1.05 & & \\
\hline \multirow{3}{*}{$\begin{array}{l}\text { Could you, please, assess the quality of the sports } \\
\text { equipment that is at disposal in your kindergarden? }\end{array}$} & $\begin{array}{l}\text { Pre-school } \\
\text { teacher }\end{array}$ & 530 & 3.68 & 0.89 & .912 & .340 \\
\hline & Assistant & 263 & 3.74 & 0.82 & & \\
\hline & Together & 793 & 3.70 & 0.86 & & \\
\hline
\end{tabular}

Legend: $\mathrm{N}$ - number of responses, annova: $\mathrm{F}=\mathrm{F}$-value, statistical significance were confirmed or rejected with the risk of $5 \%(\mathrm{p} \leq 0.05)^{*}$ 
TABLE 3

Attitude towards the motor/sports activity of the pre-school teachers and assistants

\begin{tabular}{|l|l|c|c|c|c|c|}
\hline \multirow{2}{*}{ Motor/sports activity } & & \multirow{2}{*}{$\mathbf{N}$} & \multirow{2}{*}{ Mean value } & $\begin{array}{l}\text { Standard } \\
\text { deviation }\end{array}$ & & \multicolumn{2}{|c|}{ ANOVA } \\
\cline { 3 - 7 } & & & $\begin{array}{c}\text { Statistical } \\
\text { significance }\end{array}$ \\
\hline \multirow{2}{*}{$\begin{array}{l}\text { Could you, please, assess your attitute towards mo- } \\
\text { tor/sports activity }\end{array}$} & $\begin{array}{l}\text { Pre-school } \\
\text { teacher }\end{array}$ & 527 & 4.57 & 0.6 & 3.869 & $.050^{*}$ \\
\cline { 2 - 7 } & Assistant & 263 & 4.48 & 0.7 & & \\
\cline { 2 - 7 } & Together & 790 & 4.54 & 0.6 & & \\
\hline
\end{tabular}

Legend: $\mathrm{N}$ - number of responses, annova: $\mathrm{F}=\mathrm{F}$-value, statistical significance were confirmed or rejected with the risk of $5 \%(\mathrm{p} \leq 0.05)^{*}$

mean value of all the grades is 3.70 with a standard deviation of 0.86 . The results of the analysis show that assistants awarded higher grades to the amount of sports equipment as well as to their quality. Further, the pre-school teachers assessed the amount of sports equipment (aids) at disposal in their respective kindergartens statistically lower than the assistants. The differences are also to be noted regarding quality, however they are not statistically significant.

TABLE 3 shows the attitude of the pre-school teachers to motor/sports activities and the frequency of their active participation in organized and non-organized activities. On a scale ranging from 1 to 5 , whereby 5 stands for the most and 1 for the least, the average value of all the grades is 4.5 with the standard deviation of 0.6.

On average the pre-school teachers participate in organized motor/sports activities 156.17 minutes a week, whereas in non-organized activities 248.27 minutes a week, with a standard deviation of 185.1. A more detailed analysis shows that the pre-school teachers reached higher values in all three variables. They take up 30 minutes of (organized and non-organized) activities more than the assistants per week. The assessment of the attitude towards motor/sports activities is statistically significantly different between both groups. Although there are differences in time which the preschool teachers and assistants devote to motor/sports activities, the variance analysis showed no statistically significant differences between them.

Children of those pre-school teachers and their assistants, who's opinion on the amount and quality of sports equipment at disposal in their kindergartens is higher, have better physical fitness (according to the opinions of the same teachers and assistants) (Spearman Correlation $=0.242, \mathrm{p}=0.000$ ).

\section{DISCUSSION}

The aim of this research was to establish the differences in the opinions of the pre-school teachers and the assistants as regards the quality and amount of time that children spend in kindergartens, as well as the material conditions at their disposal.

The analysis of the results showed that the opinions of the pre-school teachers and assistants regarding the manner of children spending their leisure are not statistically significantly different. In their opinions children should spend $10.1 \%$ of their leisure on average sitting outside, $28.0 \%$ is spent sitting in the play rooms and $16.8 \%$ sitting leisure time is spent in the joint premises. In her research Zajec (2009) included 37 principals of Slovenian pre-school institutions and found out that children spend most of their time in multi-purpose rooms and play rooms and that in the majority of kindergartens motor/sports activities are regularly and often performed in play rooms and multi-purpose rooms. Šetina et al. (2008) establish on the sample of 112 children, aged 5 to 8 years by means of accelometers, that the amount of motor/sports activities has been declining over the years and that the differences between girls and boys tend to grow, in favour of boys. The organization of work in the kindergarten is mainly bound to inner spaces, especially to the play rooms. Motor/sports activities should be integrated into all areas, thus enabling children an overall development and at the same time presenting them with a healthy lifestyle (Zajec, 2009). More of the children's time spent outdoors should be devoted to organized activities enabling their overall development and at the same time integrating all areas of the curriculum. Deal (1993) has also researched motor/sports activities of pre-school children. He used heart rate and log book recordings to compare daily activity patterns between children who attended day care and those enrolled in a developmental movement program. He found out that the children in the study were largely sedentary with mean heart rates ranging from 109 beats per minute to 115 beats per minute while some children did not record a single reading above 130 beats per minute for four consecutive hours. Furthermore, he came to the conclusion that children involved in a directed movement program had significantly higher activity levels than those in care. He did not find any difference between the groups during time spent at home. 
According to the Temple and O'Connor (2011) research children participate in fundamental movement skills for longer periods of time when an adult is present. All these findings should encourage pre-school teachers, their assistants and alike all adults, who deal with children, to participate in intensive movement outdoors that should be practised often enough.

Further analysis did not reveal differences in the opinions of the pre-school teachers and the assistants regarding the average values of their assessment of physical fitness of children and the frequency of their motor/sports activities. The differences were established with their assessment of the amount and quality of sports equipment, in favour of the pre-school teachers, namely. Pre-school teachers apply stricter criteria for assessment of the amount and quality of sports equipment. Temple and O'Connor (2011) found out that pre-school teachers were less assured whether assistant childcare workers provide more physical activity opportunities for children in care. The only issue mentioned across all interviews was a need for more staff and money. It seems that more than sports equipment is the knowledge and the skills of pre-school teachers. The corresponding criteria are also laid down during the study years and later at work and within in-service professional teacher training. Various authors (Alltard, 1993; Zupančič \& Kavčič, 2006; Sila, 2007) claim that the differences in the level of education are also manifested with the frequency of participating in movement activities, which in turn influences the frequency of organizing motor/sports activities in the kindergarten, as was already mentioned in the introduction. The researches (Zajec, Videmšek, Štihec, \& Šimunič, 2010; Kropej, 2001) confirm that material conditions, as well as qualified personnel influence the frequency of indulging in motor/sports activities. As regards the fact that collaboration of the pre-school teacher and assistants is needed in every phase of the educational process and that subjective theories largely influence the direction of activities of the leaders of the educational process, the authors believe that special attention on seminars of in-service professional teacher training should also be paid to assistants and this need should also be presented to the principals of kindergartens.

The analysis of the results also showed the differences in the attitude towards motor/sports activities, in favour of the pre-school teachers. We found that the pre-school teachers assess their attitudes towards motor/sports activities statistically significantly higher. Apart from that they take up organized or non-organized motor/sports activities more often, though these differences are not statistically significant. We established that pre-school teachers take up motor/sports activities a little more than 2 hours a week on average, which in the opinion of experts is the lower limit of sufficient motor/sports activities to enjoy health (Pišot \& Kropej, $2005)$. Regarding the type of profession they practise we believe that the level of sufficient motor/sports activity to be fit should be raised, because the profession of pre-school teachers and assistants demands lifting and carrying children, protecting them on climbing devices, on playing devices..., and all this requires good physical fitness from them.

At the end of the analysis of the results we established the correlation between the opinion of pre-school teachers and their assistants on children's physical fitness and the opinion on the amount and quality of sports equipment. Children of those pre-school teachers and their assistants, whose opinion on the amount and quality of sports equipment at disposal in their kindergartens is higher, have better physical fitness. We did not find out the associations between found conditions in kindergartens and the time spent with motor/sports activities. Not according to the pre-school teachers nor their assistants. As Galahue and Cleland (2003) claimed that play opportunities and instructional experiences will greatly influence the rate of development of fundamental locomotive, manipulative, and stability skills, the play opportunities and instructional experiences according to our research do not include the found conditions. This view is supported also by the research of Temple and O'Connor (2011). Therefore it is evident that children who receive age appropriate movement skill instruction in activity stimulating environments are more likely to experience success in movement tasks and consequently seek further activity opportunities (Temple \& O'Connor, 2011). It is necessary to ensure that day care environments, in which children can spend a large proportion of their time, provide the opportunities and the structure to engage children in meaningful movement experiences. Meaningful movement programs are those that allow children to learn movement skills based on sound educational principles in an interesting and organized manner (Garcia, Garcia, Floyd, \& Lawson, 2002). Temple and O’Connor (2011) also found out that pre-school teachers are concerned about their ability to provide the appropriate opportunities (such as a lack of confidence, ideas and competence) more than the conditions in kindergartens (such as sport equipment). They found out that those pre-school teachers who acquire knowledge and skills, were better able to meet the daily needs of children in their care through facilitating appropriate physical activity experiences and acting as role models.

\section{CONCLUSIONS}

The aim of this research was to establish the differences in the opinions of pre-school teachers and as- 
sistants regarding the quality and amount of time that children spend in kindergartens, as well as the material conditions at their disposal. As we already mentioned, the work obligation of an assistant provides for his collaboration with the pre-school teacher with planning, implementation and educational work preparation in the teaching group, as well as performing other tasks in connection with the activities of a pre-school institution.

In this research, the authors tried to establish if education impact the opinions of the pre-school teachers and the assistants. By knowing the differences in opinions, the authors wish to draw up guidelines by further education (preparing new subjects and reorganizing the existing one, developing new strategies in preparing seminars...) and training (developing competencies for teaching motor/sports activities) for those who have a lack of knowledge. The authors found that pre-school teachers apply stricter criteria for assessment of the amount and quality of sports equipment than their assistants. That is why the authors assumed that this could be a result of the education process.

Finally, we would like to highlight and connect our conclusions with the subjective theories. Education, lifestyle, environment, working conditions of pre-school teachers thus influences subjective theories, which have a powerful effect on the teaching orientation, and define the way and manner of a preschool teacher's activity. According to our research, we should pay more attention in education for assistants, reorganize the educational program, prepare adequate seminars etc.

All these findings lead us to the conclusion that it would be appropriate to invite preschool teachers and assistants to participate in seminars organized in the scope of in-service professional teacher training on the importance of movement during the preschool period, on the importance of quality and amount of sports equipment, and on the importance of devising a common strategy of life and work of pre-school teachers and assistants. Only life-long learning can create a healthy lifestyle in our present quickly changing society.

\section{REFERENCES}

Alltard, E. (1993). Having, loving, being: An alternative to the Swedish model of Welfare research. In M. Nussbaum \& A. Sen (Eds.), The Quality of Life (pp. 88-94). Oxford: Clarendon Press.

Bahovec, E. D., \& Kodelja, Z. (1990). Vrtci za današnji čas. Ljubljana: Center za kulturološke raziskave pri Pedagoškem inštitutu.

Deal, T. B. (1993). The preschool mover: A comparishon between naturally-occuring and program directed physical activity patterns. Early Child Development and Care, 96, 65-80.
Gabbard, C. (1988). Early childhood physical education: The essential elements. Journal of Physical Education, Recreation and Dance, 59, 65-69.

Gallahue, D. L., \& Cleland, F. (2003). Developmental physical education for all children (4th ed.). Champaign, IL: Human Kinetics.

Garcia, C., Garcia, L., Floyd, J., \& Lawson, J. (2002). Improving public health through early childhood movement programs. Journal of Physical Education, Recreation and Dance, 73, 27-32.

Kropej, V. L. (2001). Vpliv okolja na športno aktivnost predšolskih otrok. Unpublished Bachelor's thesis, University of Ljubljana, Faculty of sport, Ljubljana.

Kurikulum za vrtce. (1999). Retrieved 18. 11. 2010 from the World Wide Web: http://www.mss.gov.si

Musek, J., \& Pečjak, V. (1997). Psihologija. Ljubljana: Educy.

Pišot, R., \& Završnik, J. (2002). Z gibanjem do zdravja od otroka do starostnika. Zdrav. Var., 41(1-2), 12-15.

Pišot, R., \& Kropej, V. L. (2005). Relations between physical activity, life style and life quality indices of children and youth. In J. Novotný (Ed.), Sport a kvalita života: sborník článků a abstrakt mezinárodní konference konané 10.-11. 11. 2005 v Brně (pp. 1-16). Brno: Masarykova univerzita.

Pišot, R., Kropej, V. L., Završnik, J., Zurc, J., \& Strel, J. (2005). Child's spare time in the context of gender and environment. In T. Moris (Ed.), Promoting Health \& Performance for Life (pp. 1-4). Sydney: International Society of Sport Psychology.

Plomin, R., Chipuer, H. M., \& Neiderhiser, J. M. (1994). Behavioral genetic evidence for the importance of nonshared environment. In E. M. Hetherington, D. Reiss, \& R. Plomin (Eds.), Separate social worlds of siblings: The impact of nonshared environment on development (pp. 1-31). Hillsdale, NJ: Erlbaum.

Sanders, S. (1992). Designing preschool movement programes. Champaign, IL: Human Kinetics.

Shilton, T., \& Naughton, G. (2001). Physical activity and children. A statement of importance and call to action from the heart foundation. Retrieved 18. 12. 2011 from the World Wide Web: http://www.heartfoundation.com.au/search/index_fr.html

Sila, B. (2007). Leto 2006 in 16. študija o športnorekreativni dejavnosti Slovencev. Šport, 55(Suppl. 3), $1-11$.

Šetina, T., Volmut, T., Pišot, R., Dolenc, P., Štemberger, V., Videmšek, M. et al. (2007). Measurement of children's physical activity related to age and gender. In G. Bala (Ed.), Zbornik radova interdisciplinarne naučne konferencije sa međunarodnim učešćem antropološki status i fizička aktivnost dece, omladine i odraslih (pp. 31-40). Novi Sad: Fakultet sporta i fizičkog vaspitanja. 
Temple, A. V., \& O’Connor, J. O. (2011). Fostering physical activity for children in child care. Division of Exercise Sciences, School of Medical Sciences, RMIT University.

Videmšek, M., Pogelšek, V., Karpljuk, D., Štihec, J., \& Zajec, J. (2006). The correlation of sports activity and eating habits in pre-school children and their parents. Acta Universitatis Palackianae Olomucensis. Gymnica, 36(3), 65-73.

Videmšek, M., \& Pišot, R. (2007). Šport za najmlajše. Ljubljana: Faculty of sport, Institute of sport.

Videmšek, M., Štihec, J., \& Karpljuk, D. (2008). Analysis of pre-school physical education. Ljubljana: Faculty of sport, Institute of kinesiology.

Zajec, J. (2009). Povezanost športne dejavnosti predšolskih otrok in njihovih staršev z izbranimi dejavniki zdravega načina življenja. Unpublished doctoral dissertation, University of Ljubljana, Faculty of sport, Ljubljana.

Zajec, J. (2010). Analiza gibalnih/športnih dejavnosti otrok in vzgojiteljev kot argument za vključevanje nekaterih dejavnikov zdravega načina življenja v vrtce. In Devjak et al. (Eds.), Pedagoški koncept Reggio Emilia in Kurikulum za vrtce: podobnosti v različnosti (pp. 213-232). University of Ljubljana: Faculty of Education.

Zajec, J., \& Cemič, A. (2010). Življenjski slog bodočih vzgojiteljev. In R. Pišot \& V. Štemberger (Eds.), Sodobni pogledi na gibalni razvoj otroka: Otrok v gibanju, 6. mednarodni znanstveni in strokovni posvet, Portorož (pp. 420-423). University of Primorska: Faculty of Education of Koper.

Zajec, J., Videmšek, M., Štihec, J., \& Šimunič, B. (2010). Odvisnost organiziranih športnih dejavnosti od materialnih, vsebinskih, organizacijskih in kadrovskih vidikov za izvajanje gibanja v vrtcu. In R. Pišot et al. (Eds.), Otrok med vplivi sodobnega življenjskega sloga - gibalne sposobnosti, telesne značilnosti in zdravstveni status slovenskih otrok (pp. 87-106). Institute of Kinesiology Research, Science and Research Centre of Koper, University of Primorska: Annales.

Zakon o vrtcih. (1996). Retrieved 28. 11. 2010 from the World Wide Web: http://www.uradni-list.si/1/objava. jsp?urlid $=199612 \&$ stevilka $=569$

Završnik, J., \& Pišot, R. (2005). Gibalna/športna aktivnost za zdravje otrok in mladostnikov. Science and research centre of Koper, Koper: Annales.

Zupančič, M. (2006). The age of entry into high quality pre-school, child and family factors, and developmental outcomes in early childhood. In T. Kavčič (Ed.), European Early Childhood Education Research Journal, 14(1), 91-111.

Weiss, M. (2000). Motivating kids in physical activity. Research Digest, 3, 1-8.

\section{KVALITA PÉČE V MATEŘSKÝCH ŠKOLÁCH JAKO DŮLEŽITÝ PRVEK SUBJEKTIVNÍCH TEORIÍ}

(Souhrn anglického textu)

VÝCHODISKA: Na vzdělávacím procesu předškolních dětí v mateřských školách se společně podílí učitelé mateřských škol a asistenti. Výběr témat a zaměření výuky se odvíjí od jejich profesionality, která je také reflektována v subjektivních teoriích ovlivñujících volbu jejich životního stylu.

CÍLE: Autoři se pokouší vymezit rozdíly v názorech předškolních učitelů a asistentů na kvalitu a množství času, které děti tráví ve školkách a vymezit rozdíly $\mathrm{v}$ jejich názorech na materiální podmínky $\mathrm{k}$ realizaci pohybových/sportovních aktivit. Cílem bylo zjistit, zda předškolní učitelé uplatňují vyšší standardy, co se týče hodnocení kvality volného času, který děti tráví, a př́isnější kritéria týkající se materiálních podmínek k provádění pohybových/sportovních aktivit v mateřských školách než jejich asistenti.

METODIKA: Výzkumný vzorek se skládal z 810 předškolních učitelů a asistentů na celém území Slovinska. Data byla sbírána v září 2009 v rámci širšího výzkumu s názvem „Profesní trénink odborníků ve vzdělávání k zavádění prvků principů speciální pedagogiky dle konceptu Reggio Emilia v oblasti předškolní výchovy v letech 2008-2013“ a byla analyzována pomocí základních statistických parametrů. Data byla zpracována užitím statistického programu SPSS ve Windows. Každý statisticky významný závěr byl přijat na úrovni rizika $5 \%$.

VÝSLEDKY: Analýza výsledků ukázala, že názory předškolních učitelů a asistentů na způsob, jakým děti tráví volný čas, nebyly statisticky rozdílné. Nicméně, byly zde rozdíly týkající se hodnocení množství a kvality sportovního vybavení a rozdíly v jejich postojích $\mathrm{k}$ pohybovým/sportovním aktivitám, a to ve prospěch předškolních učitelů, kteří navíc vykonávají pohybové/sportovní aktivity častěji než asistenti. Rovněž jsme zjistili, že čím více předškolní učitelé realizují pohybové/sportovní aktivity během týdne, tím častěji také realizují pohybové/ sportovní aktivity v mateřské škole.

ZÁVĚRY: Výsledky našeho výzkumu nás vedou $\mathrm{k}$ tomu, abychom realizovali širší výběr seminářů $\mathrm{v}$ rámci profesní přípravy učitelů také pro asistenty. Zároveň také k tomu, abychom přemýšleli o poskytování rekreačních aktivit pro zaměstnance mateřských škol, které by přispěly k celkovému bio-psycho-sociálnímu postavení jednotlivce a změnily jejich životní styl ze sedavého na aktivní.

Klićová slova: asistenti, predškolní učitelé, životní styl, kurikulum. 


\section{Jera Gregorc, Ph.D.}

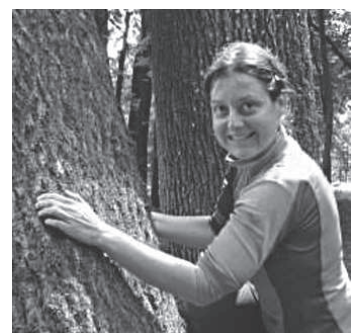

University of Ljubljana

Faculty of Education

Kardeljeva ploščad 16

1000 Ljubljana

Slovenia

\section{Education and previous work experience}

After leaving the Diocesan Classical Gymnasium in 1998, she enrolled at the Faculty of Education in Ljubljana, where she graduated in 2003. The same year she completed the first stage of a parallel study at the Theological School of the pastoral and in 2006 she graduated also as a parallel study at the Faculty of Sport. In 2009 she successfully defended a doctoral dissertation. First she worked at the Faculty of Sport as a professional colleague. Since 2008 she worked at the Faculty of Education, where she teaches several courses, however, her first occupation is a large field of motopedagogic.

\section{First-line publication}

Gregorc, J., Meško, M., Videmšek, M., \& Štihec, J. (2012). Human resource factors as an element of the quality implementation of motor activities in kindergartens. Kinesiology 44(1), 73-82.
Meško, M., Gregorc, J., Meško Štok, Z., \& Markič, M. (2012). Experiencing stress and stress symptoms among Slovene managers. Saf. Eng., 2(1), 27-31.

Gregorc, J., Videmšek, M., Meško, M., \& Štihec, J. (2012). The lifestyle and sport activity of secretaries. Sport J., 15(1). Retrieved 18. 3. 2011 from the World Wide Web: http://www.thesportjournal.org/article/ lifestyle-and-sport-activity-secretaries

Gregorc, J., Videmšek, M., Štihec, J., Karpljuk, D., Tušak, M., \& Meško, M. (2012). The lifestyle of preschool teachers and their assistants as an element of subjective theories. Zdravstveno varstvo, 5l(2), 96-106.

Gregorc, J., Videmšek, M., Štihec, J., \& Šimunič, B. (2011). Parents' opinions about their own and their children's lifestyle. Zdravstveno varstvo, 50(1), 55-63.

Gregorc, J., Videmšek, M., \& Karpljuk, D. (2007). The correlation of secretaries' sport activities and the factors of healthy life style. Šport (Ljublj.), 55(4), 70-75.

Videmšek, M., Pogelšek, V., Karpljuk, D., Štihec, J., \& Gregorc, J. (2006). The correlation of sports activity and eating habits in preschool children and their parents. Acta Universitatis Palackianae Olomucensis. Gymnica, 36(3), 65-73.

Videmšek, M., Štihec, J., Karpljuk, D., Meško, M., \& Gregorc, J. (2010). Some aspects of sports activities of pre-school children. Šport (Ljublj.), 58(1/2), $11-17$. 